\title{
ENTREVISTA
}

\section{The Only Universal Monarchy: Freemasonry, Ritual, and Gender in Revolutionary Rhode Island, 1749-1803}

The researcher Samuel Biagetti has defended a doctoral thesis, entitled "The Only Universal Monarchy: Freemasonry, Ritual, and Gender in Revolutionary Rhode Island, 1749-1803", at Columbia University in the United States of America in May, 2015. Samuel Biagetti was born in 1984 in the United States of America.

The author has granted us the following interview.

What were the reasons that led you to focus your research on Freemasonry?

I have long been interested in religion in the eighteenth century and in questioning the image of the "Enlightenment" as a secularizing age. About eight years ago, I visited the Touro Synagogue, the oldest synagogue in the United States, in Newport, Rhode Island, and the tour guide spoke about the famous exchange of letters between the rector of that synagogue, Moses Seixas, and George Washington. In visiting the cemetery, I saw Seixas' gravestone which said that he was a Mason and the Grand Master of Rhode Island. I remembered that Washington was a Mason as well, and I soon learned that the two men also held a Masonic correspondence. At this point, I realized that there was a Masonic subtext underlying much of the public life of the 1700 s.

What were the sources you used?

I used a wide range of sources of every sort that I could find - printed Masonic orations and songbooks from Rhode Island, newspaper reports, membership rolls from the lodges in Rhode Island and Jamaica, correspondence and journals from the men that I knew were Masons, ritual handbooks, implements, furniture, and jewels from the 1700s, Masonic gravestones, and a few surviving lodge logbooks from Newport, dating from the 1780 s and the late $1790 \mathrm{~s}$.

What were the main difficulties you encountered? How did you surmount them?

The largest difficulty was the lack of surviving internal records from Jamaica as well as from Providence, Rhode Island - most of the Providence lodge's records were destroyed in the massive hurricane of 1938. Another was the reluctance of some Masonic officers to 
share what records they did have. I overcame these obstacles by collecting absolutely every other source that I could find, including in personal collections archived at the Rhode Island Historical Society and Newport Historical Society, and pressing forward. After I gave a presentation at the Newport Historical Society, Masons were more forthcoming in allowing me to see their surviving records.

What major historical problems has your work resolved?

Historians often want to slot Freemasonry into some pre-existing political category-protorevolutionary democracy, Enlightenment secularism, or bourgeois class interests, etc. I tried to approach the Fraternity without political preconceptions, and I found that in fact the driving forces of the Craft were emotional and religious. It satisfied the need for surrogate kin and a sense of stability in a very unstable world. The Rhode Island Masons, for example, were deeply divided over the America Revolution, but almost to a man they put great stock in the Fraternity's myths and rituals and in the emotional bonds that they shared. Those myths and rituals have their roots in a deep stratum of esoteric and shamanistic thought as well as in the Jacobite movement, the secretive political wing that sought to restore the deposed Stuart dynasty to the British throne. In America, Masonry's political influence truly came after the Revolution, when Masons helped to create a new, stable civic order in the absence of the monarch.

Please, could you summarize the essence of your thesis in two lines?

Freemasonry in the 1700 s was fundamentally driven by myth, ritual, and emotion. While it did not spark the American Revolution, it did help to create a strong civic order for the new republic that could replace the lost monarch.

What were the lessons, at all levels, personal and professional, that you have deducted from your research experience?

Research a topic that you think is truly important, not simply what tenure boards want to hear about, and not what you happen to already have a pile of documents about. Some of my advisors at Columbia, though supportive of my ideas, were skeptical that there were enough sources to write about Masonry in Rhode Island or the Caribbean. In fact, sources of all sorts existed, and various people-Rhode Island and Jamaica Masons as well as archivists - helped me to find what survived. Ask, and it shall be given you; seek, and ye shall find; knock, and it shall be opened unto you. 
Now, what are your professional plans?

I am applying to academic positions at various institutions in the United States and Canada, and along with a friend, I have also begun an antique dealership, Labyrinth Antiques, www.labyrinthantiques.com.

Would you like to highlight an aspect that has not been covered and you consider worthy of review?

Scholars such as Margaret Jacob have described the eighteenth-century lodges as "schools of government" that taught men and women to govern themselves democratically and constitutionally, paving the way for revolutions and for liberal democracy. However, lodges specifically prohibited canvassing for votes or electioneering; in 1796 the Provincial Grand Lodge of Jamaica even threw out the results of the elections in Union Lodge because one candidate had canvassed for votes. Elections were pro forma, with the oldest and most experienced Masons always taking the highest offices. The "harmony" that Masons so zealously guarded within their lodges entailed the suppression of anything that looked like modern-day democracy; emotion trumped politics.

This interview was done Oct. $14^{\text {th }}, 2015$.

Authors of the Interview: Ricardo Martínez Esquivel and Yván Pozuelo Andrés, Director and Editor REHMLAC+.

DOI: http://dx.doi.org/10.15517/rehmlac.v7i2.22764 